\title{
Laatu- ja vastuukysymysten kohtaaminen elintarvikeketjun rajapinnoilla
}

\author{
Jaana Paananen ${ }^{1)}$, Inkeri Pesonen ${ }^{2)}$, Merja Isoniemi ${ }^{3)}$, Johanna Mäkelä ${ }^{3)}$, Sirpa Kurppa ${ }^{2)}$ ja \\ Sari Forsman-Hugg ${ }^{1)}$ \\ ${ }^{1)}$ MTT Taloustutkimus, Luutnantintie 13, 00410 Helsinki, jaana.paananen@mtt.fi, \\ sari.forsman-hugg@mtt.fi,puh. (09) 56080 \\ ${ }^{2)}$ MTT Ympäristöntutkimus, 31600 Jokioinen, inkeri.pesonen@mtt.fi, sirpa.kurppa@mtt.fi \\ ${ }^{3)}$ Kuluttajatutkimuskeskus, PL 5, 00531 Helsinki, merja.isoniemi@kuluttajatutkimuskeskus.fi, \\ johanna.makela@kuluttajatutkimuskeskus.fi
}

Laatutyö on olennainen osa suomalaista elintarvikeketjua. Tuotteiden ja toiminnan laadun ohella viime vuosina keskusteluissa on nostettu esiin yhteiskuntavastuullisen toimintatavan vahvistaminen elintarvikeketjussa. Myös Suomen kansallisessa laatustrategiassa vastuullisuus on kirjattu keskeiseksi elintarviketaloutta ohjaavaksi arvoksi. Yhteiskuntavastuulla tarkoitetaan yrityksen aktiivista vastuullisuutta, joka perustuu yrityksen omista lähtökohdista asetettuihin arvoihin ja strategioihin. Yhteiskuntavastuun kantaminen tarkoittaa yritykseen kohdistettujen odotusten täyttämistä.

Laatu- ja vastuukysymyksiä eri toimijoiden rajapinnoilla tarkastelevassa tutkimuksessa eräänä teoreettisena lähtökohtana oli yhteiskuntavastuu käsitteenä. Kirjallisuuden mukaan yhteiskuntavastuu jaetaan kolmeen osa-alueeseen: taloudelliseen vastuuseen, sosiaaliseen vastuuseen ja ympäristövastuuseen. Tavoitteena oli tutkia miten elintarvikeketjun eri toimijat määrittelevät laatu- ja vastuukysymyksiä ja miten laaja-alaiseksi vastuu koetaan oman yrityksen tai organisaation näkökulmasta suhteessa muihin toimijoihin. Tarkastelua suunnattiin erityisesti toimijoiden välisiin vuorovaikutussuhteisiin, miten laatu- ja vastuukäsitykset kohtaavat ketjun toimijoiden rajapinnoilla. Tämän tarkastelun teoreettisena lähtökohtana tutkimuksessa oli ketju- ja verkostojohtamisen näkökulma (Chain ja network management).

Tutkimusta varten haastateltiin henkilökohtaisesti kaikkiaan 61 toimijaa elintarvikeketjun eri osista: panosteollisuuden edustajat, viljelijät, elintarviketeollisuuden ja -kaupan edustajat, kuluttajat sekä viranomaiset ja elinkeinon edunvalvojat. Haastattelujen pohjana oli yhtenäinen teemarunko, jota tarpeen mukaan räätälöitiin haastateltavan ja hänen edustamansa tahon mukaan. Haastattelurunko sisälsi seuraavat pääteemat: 1) laatu, 2) tuoteturvallisuus, 3) jäljitettävyys ja alkuperä, 4) elintarvikeketjun läpinäkyvyys 5) vastuu yleisesti, 6) ympäristövastuu, 7) sosiaalinen vastuu, 8) taloudellinen vastuu, 9) vastuusta viestiminen ketjun rajapinnoilla sekä 10) vastuu ja vaikutusmahdollisuudet. Tutkimusta varten valittiin kolme esimerkkituotetta, jotka ohjasivat haastateltavien valintaa ja joiden avulla konkretisoitiin laatuun ja vastuuseen liittyviä kysymyksiä. Esimerkkituotteet olivat marinoidut broilerinfileet, tuore mansikka / mansikkahillo sekä juustokermaperunat.

Aineiston käsittelyssä hyödynnettiin kehysanalyysiä. Ensimmäisessä vaiheessa aineisto luokiteltiin teemoittain ja toimijoittain. Tämän jälkeen eri toimijoiden samaan teemaan kuuluvat aineistot järjestettiin tulkintakehikkoon sisällön tarkastelua varten. Tulkintakehikon avulla tarkasteltiin erityisesti eri käsitteiden sisältöä ja ulottuvuuksia. Tulokset ovat tässä vaiheessa osittain alustavia.

Tulokset kertovat, minkä tekijöiden kautta vastuuta elintarvikeketjussa voidaan jäsentää. Tutkimus osoittaa, että elintarvikeketjun eri toimijoiden toiminnan vastuullisuus omassa yrityksessä tai organisaatiossa liittyy keskeisesti tuotelaatuvastuuseen ja vastuuseen tuotteen turvallisuudesta. Alkutuotannon ja teollisuuden rooli on tuotelaadun tuottaminen, ja elintarvikekaupan ja kuluttajien tehtävänä on hyvän tuotelaadun säilyttäminen. Käsitykset vastuukysymyksistä elintarvikeketjussa ja kuluttajilla olivat osin jaettuja, osin näkemykset vaihtelivat. Käsitteiden tarkastelun lisäksi esityksessä tullaan ottamaan kantaa myös siihen, miten yhteiskuntavastuu ja kotimaisen elintarvikeketjun laatutyö linkittyvät toisiinsa ja mitkä ovat niitä rajapintoja, joissa laatu- ja vastuukysymyksistä kommunikointi aiheuttaa ongelmia.

Asiasanat: laatu, vastuu, yhteiskuntavastuu, elintarvikeketju, kuluttaja 


\section{Johdanto}

Laatutyö on olennainen osa suomalaista elintarvikeketjua. Tuotteiden ja toiminnan laadun ohella viime vuosina keskusteluissa on nostettu esiin yhteiskuntavastuullisen toimintatavan vahvistaminen elintarvikeketjussa. Myös Suomen kansallisessa laatustrategiassa vastuullisuus on kirjattu keskeiseksi elintarviketaloutta ohjaavaksi arvoksi (www.laatuketju.fi). Yhteiskuntavastuulla tarkoitetaan yrityksen aktiivista vastuullisuutta, joka perustuu yrityksen omista lähtökohdista asetettuihin arvoihin ja strategioihin. Yhteiskuntavastuun kantaminen tarkoittaa yritykseen kohdistettujen odotusten täyttämistä. Yritys, joka lupaa olla yhteiskunnan vastuullinen jäsen, sitoutuu toimimaan eettisesti, toisin sanoen se sitoutuu kestävään kehitykseen, joka luo tasapainon talouden, ihmisen ja ympäristön välille (Kalpala 2004).

Yhteiskuntavastuuseen sisältyvän taloudellisen vastuun ulottuvuuksia ovat liiketoiminnan kannattavuus, kilpailukyky ja tehokkuus, omistajien tuotto-odotuksiin vastaaminen sekä yhteiskunnan taloudellisen hyvinvoinnin tuottaminen. Vastuullinen yritys ei kuitenkaan pyri omistajien tuottoodotuksiin hinnalla millä hyvänsä vaan kestävän kehityksen ehdoilla. Ympäristövastuun ulottuvuuksia ovat vesien, ilman ja maaperän suojelu, ilmastonmuutoksen torjunta, luonnon monimuotoisuuden turvaaminen; tehokas ja säästävä luonnonvarojen käyttö sekä vastuu tuotteen elinkaaresta ja toiminnan arvoketjusta. Sosiaalisen vastuun ulottuvuuksia ovat henkilöstön hyvinvointi ja osaaminen, tuotevastuu ja kuluttajasuoja, hyvät toimintatavat yritysverkostossa sekä lähiyhteisö- ja yhteiskuntasuhteissa, ihmisoikeudet sekä yleishyödyllisten toimintojen tukeminen (Kalpala 2004, Niskala ja Tarna 2003, Teollisuus ja Työnantajat 2004).

Suomessa yhteiskuntavastuuseen liittyvää tutkimusta on tehty parin vuosikymmenen ajan. Takala $(1986,1991)$ on luonut pohjaa käsitteistölle tutkimalla yhteiskunnallisen vastuun käsitettä sekä yrityksen yhteiskunnallista vastuuta ja yritystoiminnan ideologioita eri vuosikymmeninä. Väitöskirjatason tutkimusta ovat tehneet myös Kujala (2001), Lämsä (2001), Virtanen (2002) ja Rytteri (2002). He ovat tutkineet yritysetiikkaa, moraalista päätöksentekoa ja yritysten yhteiskuntavastuuta eri näkökulmista. Meneillään on useissa yliopistoissa väitöskirjatutkimuksia yhteiskuntavastuusta ja vastuullisesta yrittäjyydestä sekä yritysetiikasta eri toimialoilla. Elintarvikealan eri toimijoiden vastuullisuutta tarkasteleva tutkimus on ajankohtainen. Yhtäällä alalla vallitsevat kilpailun paineet johtavat kiristyvään alhaisempien kustannusten strategiaan ja toisaalla elintarviketurvallisuus, alkuperämerkinnät, elintarvikkeiden tarjontaketjun jäljitettävyys ja toiminnan läpinäkyvyys ovat keskeisiä vastuullisuuteen liittyviä tekijöitä.

Vaikka keskustelu yhteiskuntavastuun merkityksestä onkin lisääntynyt elintarvikealalla, ja monet yritykset ovat raportoineet yhteiskuntavastuuseen liittyvistä asioita vuosikertomuksissaan ja kotisivuilla (ks. Elintarviketeollisuusliitto 2004, 2005), toistaiseksi ei ole yhteistä ymmärrystä siitä, mitä liiketoiminnan vastuullisuudella elintarvikeketjussa tarkoitetaan, miten vastuullisuus käsitteellisesti linkittyy elintarvikeketjun laatutyöhön ja miten siitä kommunikoidaan ketjun muiden toimijoiden kanssa. Keskeisenä vastuullisuuden kehittämisen haasteena onkin juuri se, kuinka vastuullisuus syntyy ja jäsentyy eri sidosryhmien välisenä vuoropuheluna (Wilenius 2005). Tämän artikkelin tavoitteena on selvittää, miten elintarvikeketjun eri toimijat määrittelevät laatu- ja vastuukysymyksiä ja miten laajaalaiseksi toimijat kokevat vastuunsa suhteessa muihin toimijoihin. Tässä esityksessä tarkastelua suunnataan erityisesti toimijoiden välisiin vuorovaikutussuhteisiin, miten laatu- ja vastuukäsitykset kohtaavat ketjun toimijoiden rajapinnoilla. Artikkeli perustuu MTT:n ja Kuluttajatutkimuskeskuksen yhteistutkimukseen "Laatu ja vastuu elintarvikeketjussa" (2004-2005). Tutkimusta rahoittaa Maa- ja metsätalousministeriö.

\section{Aineisto ja menetelmät}

Tutkimus toteutettiin kvalitatiivisella tutkimusotteella, koska yleistettävän tiedon sijaan tavoiteltiin mahdollisimman paljon erilaisia näkökulmia lähestyä laatua ja vastuullisuutta elintarvikeketjussa. Tutkimusta varten haastateltiin henkilökohtaisesti kaikkiaan 61 toimijaa elintarvikeketjun eri osista: panosteollisuuden edustajat, viljelijät, elintarviketeollisuuden ja -kaupan edustajat, kuluttajat sekä viranomaiset ja elinkeinon edunvalvojat. Haastattelut tehtiin lokakuun 2004 ja maaliskuun 2005 välisenä aikana. Taulukossa 1 esitetään haastatellut kohteet ja haastattelujen lukumäärä toimijaryhmittäin.

Haastattelujen pohjana oli yhtenäinen teemarunko, joka sisälsi seuraavat pääteemat: 1) laatu, 2) tuoteturvallisuus, 3) jäljitettävyys ja alkuperä, 4) elintarvikeketjun läpinäkyvyys 5) vastuu yleisesti, 6) ympäristövastuu, 7) sosiaalinen vastuu, 8) taloudellinen vastuu, 9) vastuusta viestiminen ketjun raja- 
pinnoilla sekä 10) vastuu ja vaikutusmahdollisuudet. Tutkimusta varten valittiin kolme esimerkkituotetta marinoidut broilerinfileet, tuore mansikka / mansikkahillo sekä juustokermaperunat. jotka ohjasivat haastateltavien valintaa ja joiden avulla konkretisoitiin laatuun ja vastuuseen liittyviä kysymyksiä.

Taulukko 1. Haastattelujen lukumäärä $(\mathrm{N}=61)$ elintarvikeketjun toimijaryhmissä.

\begin{tabular}{|c|c|c|}
\hline Toimijaryhmä & $\begin{array}{l}\text { Haastattelujen } \\
\text { lukumäärä }\end{array}$ & Haastateltavien edustama toimiala ja/tai haastateltavien kuvaus \\
\hline Panosteollisuus & 5 & $\begin{array}{l}\text { rehuteollisuus (2), lannoiteteollisuus (1), kalkkikiviteollisuus (1), torjunta- } \\
\text { aineiden maahantuoja (1) }\end{array}$ \\
\hline Alkutuotanto & 12 & $\begin{array}{l}3 \text { perunantuottajaa, } 3 \text { mansikanviljelijää, } 2 \text { maidontuottajaa, } \\
3 \text { broilerintuottajaa, } 2 \text { sokerijuurikkaan tuottajaa }\end{array}$ \\
\hline Elintarviketeollisuus & 12 & $\begin{array}{l}\text { siipikarjanlihan jalostus (4), marjojen jalostus (4), sokeriteollisuus (1), } \\
\text { valmisruokatuotteiden valmistus (2), meijerituotteiden valmistus (1) }\end{array}$ \\
\hline Elintarvikekauppa & 9 & $\begin{array}{l}\text { kaupparyhmittymät/keskusliikkeet (5), kaupan logistiikkayritykset (2), } \\
\text { vähittäiskaupan edustajat (2) }\end{array}$ \\
\hline Kuluttajat & 16 & $\begin{array}{l}\text { naisia } 11 \text {, miehiä } 5 ; 9 \text { pääkaupunkiseudulta, } 7 \text { maaseutualueilta; } 11 \text { lapsiper- } \\
\text { heistä, } 5 \text { yhden/kahden hengen talouksia }\end{array}$ \\
\hline $\begin{array}{l}\text { Edunvalvojat/ } \\
\text { viranomaiset }\end{array}$ & 7 & $\begin{array}{l}\text { Elintarviketeollisuusliitto, Elintarvikevirasto, Kuluttajat Konsumenterna ry, } \\
\text { MTK, Päivittäistavarakauppayhdistys, } 2 \text { elintarvikevalvonnan edustajaa }\end{array}$ \\
\hline
\end{tabular}

Aineiston käsittelyssä hyödynnettiin kehysanalyysiä. Ensimmäisessä vaiheessa aineisto luokiteltiin teemoittain ja toimijoittain. Tämän jälkeen eri toimijoiden samaan teemaan kuuluvat aineistot järjestettiin tulkintakehikkoon sisällön tarkastelua varten. Tulkintakehikon avulla tarkasteltiin erityisesti eri käsitteiden sisältöä ja ulottuvuuksia. Tulokset ovat tässä vaiheessa osittain alustavia.

\section{Tulokset ja tulosten tarkastelu}

Tulokset osoittavat, että elintarvikeketjun eri toimijoilla on suhteellisen yhtenäinen näkemys tuotteen laadusta ja ketjun eri toimijoiden laatuodotuksista. Panosteollisuudessa laatu määriteltiin asiakaslähtöisesti; tuote on käyttötarkoitukseen sopiva ja asiakkaan tarpeita vastaava, lisäksi asiakkaan on voitava luottaa tuotteen kokonaislaatuun. Sekä alkutuotannon että elintarviketeollisuuden edustajat kuvasivat laatua tarkasti tuotteen objektiivisena ja tuotantotoiminnan laatuna, joka on yleensä ketjun seuraavan toimijan vaatimuksena ja ketjussa toimimisen edellytyksenä. Lisäksi korostettiin tuotteen laadun muodostuvan sekä lainsäädännön tuotteelle asettamista vaatimuksista että kuluttajien odotuksista. Elintarvikekaupan edustajat painottivat vahvasti laadun muodostuvan asiakkaan kokemasta tuotteen ja palvelun laadusta.

Kuluttajille laadusta viestivät tekijät liittyvät yhtäältä odotuksiin ja kokemuksiin tuotelaadusta ja tuotteen hintalaatusuhteesta sekä toisaalta mielikuviin, joiden herättäjinä voivat olla mm. tuotteen alkuperä, valmistaja, tuotepakkaus, mainonta, tuotetieto ja ostotilanteeseen sidotut tekijät kuten kauppa palveluineen. Vastuullinen laaduntuottaminen ja säilyttäminen konkretisoitui myös kuluttajilla hyvin pitkälle tuotteiden turvalliseen käyttöön. Haastattelujen ja esimerkkinä käytettyjen tuotteiden kontekstissa, kuluttajat määrittelivät "hyvälaatuiselle tuotteelle" vähimmäisvaatimukset, joihin he ostajina ovat oikeutettuja. Näihin vähimmäisvaatimuksiin kuuluu, ettei tuotteiden lyhyt- ja pitkäaikaisesta käytöstä aiheudu käyttäjilleen terveydellistä vaaraa ja, että tuotteet ovat moitteettomassa kunnossa myyntihetkellä ja tarjoavat tässä mielessä vastinetta niistä suoritetulle hinnalle.

\section{Tuoteturvallisuus}

Tuoteturvallisuudesta oli myös yhtenäinen käsitys ketjun toimijoiden kesken; tuoteturvallisuus on peruslaatutekijä ja -vaatimus, ei kilpailutekijä elintarvikeketjussa. Kaikki ketjun toimijat linkittivät tuoteturvallisuuden keskeiseksi osaksi laatua ja laatutyötä. Turvallinen elintarvike on sellainen, joka ei aiheuta mikrobiologista riskiä käyttäjälle, eikä eläinten tai ihmisten sairastumista. Kaupan edustajat korostivat myös, että tuotepakkaukseltaan ehjä ja aistittavalta laadultaan hyvä elintarvike on turvallinen. Myös kuluttajille tuoteturvallisuus oli keskeinen laatutekijä, niinpä turvallisista elintarvikkeista viestivät tekijät olivat hyvin usein samoja kuin laadusta viestivät. Turvallisuuden varmistamisessa keskeisimmälle sijalle kuluttajat nostivat yhtäältä tuotteiden oikean käsittelyn ja säilytyksen ja toisaalta niiden tuoreuden. Elintarvikkeiden laadun ja turvallisuuden ylläpitämisessä korostettiin erityisesti kylmäketjun katkeamattomuuden merkitystä ja jokaisen ketjun linkin ja kuluttajan vastuullista toimin- 
taa tässä asiassa. Päiväysmerkinnät, ehjät tuotepakkaukset ja tuotteiden ulkoinen moitteettomuus ovat konkreettisia keinoja kuluttajalle varmistua hankintahetkellä tuotteiden turvallisuudesta.

\section{Jäljitettävyys}

Kaikki elintarvikeketjun toimijat kokivat jäljitettävyyden elintarvikeketjussa erittäin tärkeänä elintarvikkeiden turvallisuuden ja mahdollisten ongelmien selvittämiseksi. Alkutuotannon edustajat korostivat, että jäljitettävyys on tärkeää tuotteiden kotimaisuuden varmistamiseksi. Esimerkiksi suomalaisen siipikarjalihan alkuperä on luotettavasti ja yksinkertaisesti selvitettävissä, ja jäljitettävyys voitaisiin siten nostaa yhdeksi kilpailutekijäksi elintarvikeketjussa.

Sen sijaan elintarviketeollisuuden ja kaupan edustajat kokivat jäljitettävyyden enemmän osaksi laadun ylläpitämistä ja omavalvontaa kuin mahdollisena kilpailutekijänä. Jäljitettävyys on tärkeää tuotteen alkuperän selvittämiseksi, laatuketjun ylläpitämiseksi, palautteen perille saamiseksi sekä kustannusten ja riskien hallitsemiseksi. Lisäksi kauppa korosti, että jäljitettävyys on myös kuluttajille osa tuoteturvallisuutta ja kuluttajan hyvinvointia; kuluttajat haluavat tietää tuotteen alkuperän. Kuluttajien tulee voida luottaa elintarvikeketjun toimintaan, ja heidän on saatava riittävät tuotetiedot ostopäätöksensä tueksi.

Yksityiskohtaisen, lähinnä raaka-aineiden sisäisen jäljitettävyyden toteuttamisen taso herätti sekä elintarviketeollisuuden että kaupan edustajien keskuudessa myös kysymyksiä ja pohdintaa. Mikä on jäljitettävyyden osalta järkevä toteuttamistapa ja tarkkuustaso, jossa kustannukset ja työ eivät ylitä saavutettuja hyötyjä? Minkä tason jäljitettävyydestä on erityisesti kuluttajille hyötyä? Onko yrityksen mahdollista saavuttaa ylivoimaisilla jäljitettävyystiedoilla kilpailuetua verrattuna muihin yrityksiin? Vastuu jäljitettävyyden toteutumisesta kulkee yksi porras eteenpäin ja yksi taaksepäin periaatteella koko ketjun läpi, ja tämän tason eli toimittaja- ja asiakasjäljitettävyyden katsotaan toteutuvan tällä hetkellä elintarvikeketjussa.

Myös kuluttajat pitivät jäljitettävyyttä elintarvikeketjussa tärkeänä. Jäljitettävyys on elintarvikeketjun toimijoiden "työväline", jonka avulla ongelmatilanteissa voidaan tarvittavat toimet kohdistaa nopeasti oikeaan kohteeseen elintarvikeketjua. Tässä mielessä jäljitettävyys on osa laadun ja turvallisuuden varmistamista ja myös osa kuluttajasuojaa. Kuluttajasuojan toteutumiseksi on tärkeää, että elintarvikeketjun toimijoilla on dokumentoitua tietoa elintarvikkeiden läpikäymistä vaiheista ketjussa. Lisäksi jäljitettävyyden avulla kuluttaja voi halutessaan saada tietoa tuotteiden alkuperästä, valmistajasta, tuotantotavasta ja vaiheista elintarvikeketjussa.

\section{Läpinäkyvyys}

Läpinäkyvyys koettiin eri toimijoiden keskuudessa jäljitettävyyttä laajempana ja osittain myös epämääräisenä käsitteenä. Jäljitettävyys käsittää tuote- ja toimittajatietoja, kun läpinäkyvyydellä ymmärrettiin näiden lisäksi myös yrityksen toimintatapojen avoimuutta. Toiminnan avoimuudella tarkoitettiin tietoa ketjun eri toimijoiden toimintatavoista ja periaatteista sekä myös ympäristön olosuhteista, minkälaisessa ympäristössä prosessia toteutetaan. Läpinäkyvyys on alkutuotannon ja elintarviketeollisuuden mukaan parhaimmillaan toimijan rehellisyyttä, mikä vahvistaa toimijoiden välistä luottamusta sekä viljelijä-yrittäjien ja elintarvikeyritysten jalostustyön arvostusta elintarvikemarkkinoilla.

Kuitenkin täysin avoimessa yritystoiminnassa ja yksityiskohtaisen läpinäkyvyyden tavoittelussa koettiin olevan myös tekijöitä, jotka ovat osa yrityksen liikesalaisuutta. Liikesalaisuudeksi kuuluvana pidettiin esimerkiksi elintarvikeyrityksen valmistusreseptiikkaa, joka on yrityksen tärkeä pääoma ja jonka avulla yritys tekee mahdollisesti voittoa. Valmistusreseptiikan lisäksi liikesalaisuudeksi kuuluvana pidettiin yksityiskohtaista tietoa myös yrityksen hinnoittelupolitiikasta, raaka-aineiden alkuperästä, yhteistyökumppaneista ja yrityksen palkkapolitiikasta.

Kuluttajille läpinäkyvyys tarkoittaa ennen muuta avointa ja rehellistä toimintatapaa. Tällainen toimintatapa pitää sisällään mm. sen, että elintarvikkeiden läpikäymien vaiheiden tulisi olla helposti viranomaisten ja esimerkiksi ketjun seuraavan lenkin tarkastettavissa ja valvottavissa. Tämä edellytys liittyy kuluttajilla käsityksiin vastuullisesta toiminnasta ketjussa; elintarvikeketjun toimijoiden vastuullisuuteen lasketaan kuuluvaksi mm. yhteistyötahojen toiminnan vastuullisuudesta varmistuminen. Avoimuuden tulee läpinäkyvässä elintarvikeketjussa kohdistua myös kuluttajille suunnattuun tiedottamiseen. 


\section{Yleinen käsitys vastuusta}

Käsitykset vastuukysymyksistä elintarvikeketjussa olivat osin jaettuja, osin näkemykset vaihtelivat ketjun eri osissa. Elintarvikeketjun eri toimijoiden keskuudessa vastuu liitettiin vahvimmin vastuuseen korkeasta tuotelaadusta ja turvallisuudesta ja sekä vastuuseen omasta toiminnasta lain asettamien reunaehtojen mukaisesti. Tuotteiden laadun ja yritystoiminnan on oltava yrityksen lupausten ja sidosryhmien sekä asiakkaiden odotusten mukainen. Myös alkutuotannossa vastuu koettiin tuotelaatua laajempana. Viljelijä-yrittäjät kantavat vastuuta eläinten hyvinvoinnista, EU-säännösten noudattamisesta, korkeasta työmoraalista ja itsensä kehittämisestä.

Elintarvikekaupan edustajat kokivat vastuunsa kohdistuvan ensisijaisesti kaupan ja kuluttajan väliseen rajapintaan, jossa asiakaspintana on koko Suomen väestö. Omassa toiminnassaan kauppa on vastuussa omavalvonnan toteutumisesta, tuotteen myynnistä ja tuotehävikin minimoimisesta sekä lisääntyvässä määrin lajittelusta ja jätehuollosta. Kokonaisuudessaan ketjun eri toimijoiden toiminnan korostettiin olevan tasapuolisesti vastuullista johtuen kilpailun asettamista vaatimuksista. Elintarvikeketjussa kukin toimija varmistaa edellisen toimijan laadun ja tuotteen hallinta määrittää vastuun. Tuotetasolla elintarviketeollisuus koki olevansa täysin vastuussa valmistamistaan omista brandi-tuotteista. Vastaavasti kaupan private label -tuotteista elintarviketeollisuus ei kokenut olevansa vastuussa samassa määrin, vaan vastuu jaetaan teollisuuden ja kaupan sopimuksen mukaisesti. Elintarviketeollisuuden ja kaupan edustajat osoittivat kiinnostusta erityisesti siihen, mitä kuluttajat vastuullisuudella ymmärtävät ja minkälaista vastuullisuutta he teollisuudelta ja kaupalta odottavat.

\section{Taloudellinen vastuu}

Taloudellinen vastuu nähtiin elintarvikeketjussa toiminnan peruslähtökohtana; toiminnan tulee olla kannattavaa ketjun kaikille toimijoille. Lisäksi panos- ja elintarviketeollisuuden edustajat sekä kuluttajat liittivät taloudelliseen vastuuseen liiketoiminnan jatkuvuuden ylläpitämisen. Esimerkiksi sopimustuottajien kanssa yhteistyössä olevat elintarviketeollisuuden edustajat korostivat, että heillä on vastuu informoida viljelijä-yrittäjiä kulutusennusteista. Elintarvikeyrityksen on vastuutonta kannustaa viljelijä-yrittäjiä ylituotantoon edullisemman hinnan toivossa. Korostettiin, että suomalainen elintarviketeollisuus ei kilpaile hinnalla vaan sen kilpailutekijöitä ovat erilaistuminen, korkea osaamisen taso ja suomalaiset makutottumukset. Lisäksi muutamat toimijat korostivat, että taloudellista vastuuta on myös olla myymättä tuotteita alle sisäänostohinnan tai omien tuotantokustannusten ja myyntikatteen. Muutamat toimijat osoittivat huolensa kaupan vastuuseen elintarvikkeiden hinnanasetannassa. Kaupan kokema taloudellinen vastuu linkittyi vahvasti kannattavuuden lisäksi juuri kustannustehokkuuden ja kilpailukyvyn ylläpitämiseen.

Keskeistä kuluttajien näkemyksissä taloudellisesta vastuusta oli elintarvikeketjussa toimivien yritysten laaja-alainen vastuu kestävästä toiminnasta. Kestävään toimintaan sisällytettiin ennen muuta toiminnan kannattavuus ja toiminnan jatkuvuudesta huolehtiminen ja näin vastuunkanto yrityksen työntekijöistä ja työllisyydestä. Taloudellista vastuuta on myös, että tulonjako elintarvikeketjussa on oikeudenmukainen, mukaanlukien vastuu elintarvikkeiden hintakehityksestä.

\section{Sosiaalinen vastuu}

Kaikki elintarvikeketjun toimijat liittivät sosiaaliseen vastuuseen vahvimmin oman henkilöstön, työntekijöiden hyvinvoinnin ja työpaikkojen säilymisen. Ketjun alkupäässä, panosteollisuudessa ja alkutuotannossa sosiaaliseen vastuuseen katsottiin sisältyvän myös eläinten hyvinvointi ja eettiset tuotantotavat. Vastaavasti elintarviketeollisuudessa oli useimmiten vasta pohdinnan alla, mitä kaikkea sosiaalisen vastuun käsitteen piiriin voidaan sisällyttää. Kaupan toimijat liittivät sosiaaliseen vastuuseen oman henkilöstön lisäksi tavarantoimittajiin liittyvät kysymykset.

Sekä elintarviketeollisuuden että kaupan edustajat katsoivat, että esimerkiksi terveellisten ruokatottumusten edistäminen on luonteva osa sosiaalista vastuunkantoa. Siitä, kenen vastuulle terveellisten ruokatottumusten edistäminen kuuluu, oli monenlaisia näkemyksiä. Joidenkin mielestä vastuun jakaantumisesta teollisuuden ja kaupan välillä ei ole vielä tarpeeksi keskusteltu. Vastaavasti osa oli sitä mieltä, että teollisuuden vastuu on kehittää ja valmistaa kaupalle ja kuluttajille terveellisiä tuotteita. Lopulta myös korostettiin kuluttajilla itsellään olevansa vastuu valita kaupan monipuolisesta valikoimasta itselleen terveelliset vaihtoehdot. Pakkaus- tai hintapolitiikalla ei katsottu olevan merkittävää vaikutusta terveellisten ruokatottumusten edistämisessä. Erikokoisten pakkausten koetaan palvelevan erilaisia kuluttajaryhmiä. 
Kuluttajat sisällyttivät sosiaalisen vastuun käsitteeseen osin samoja asioita kuin taloudelliseen vastuuseen. Yksi keskeinen elementti sosiaalisessa vastuussa ovat yrityksen työntekijät. Sosiaaliseen vastuuseen luetaan mukaan työllisyydestä ja asianmukaisista työoloista ja työsuojelusta huolehtimisen lisäksi mm. osavastuu työntekijöiden työtä arvostavasta työkulttuurista. Toinen elementti sosiaalisessa vastuussa on yrityksen lähiympäristön ottaminen huomioon. Kuluttajien hyvinvointi on kolmas keskeinen sosiaalisen vastuun kohdealue. Tämä tarkoittaa laadukkaiden, terveellisten ja turvallisten tuotteiden tuottamista, jakelua ja kauppaa.

\section{Ympäristövastuu}

Kaikki elintarvikeketjun toimijat liittivät ympäristövastuuseen vahvimmin ympäristökuormitusten vähentämisen ja asetettujen standardien ja säädösten noudattamisen. Alkutuotannossa korostettiin myös vastuuta maaseutumaiseman huolehtimisesta. Elintarviketeollisuudessa ja kaupassa ympäristövastuuseen liitettiin lisäksi kierrätyksen ja jätehuollon kehittäminen sekä energian käytön tehostaminen. Sen sijaan epäselvyyttä on sivutuoteasetuksen aiheuttamien toimien ja vastuun jakaantumisesta elintarvikeketjussa. Vuoden 2006 alusta alkaen myymälöissä joudutaan erotteleman eläinperäinen ruokajäte muusta biojätteestä erillistä kuljetusta ja käsittelyä varten.

Kuluttajille tärkeää ympäristövastuun kannossa olivat myös tuotannossa, kaupassa ja kulutuksessa syntyvien jätteiden hävittäminen, tuotteiden pakkaustapa ja pakkausmateriaalien kierrätettävyys tai helppo hävitettävyys. Vaikka ympäristövastuullisen toiminnan pääasiallisina kohteina miellettiin luonnonympäristöön kohdistuvat toimenpiteet, tämän lisäksi siihen katsotaan kuuluvan yhtenä tärkeänä osana eläinten hyvinvointi.

\section{Vastuusta viestiminen ketjun rajapinnoilla}

Laatuun ja vastuullisuuteen liittyvistä asioista puhutaan panosteollisuuden, alkutuotannon ja jalostavan teollisuuden välisessä yhteistyössä. Panos- ja elintarviketeollisuudessa sekä kaupan alalla laadusta ja vastuullisuudesta viestitään ja joidenkin yritysten osalta myös raportoidaan sidosryhmille ja kuluttajaasiakkaille. Kuitenkin muutamat elintarvikeyrityksen ja kaupan edustajat nostivat esille useita kysymyksiä liittyen vastuusta viestimiseen. Erityisesti pohdittiin kuluttajien tuotteille asettamia valintakriteerejä ja vastuullisuuden linkittämistä ostopäätösten tueksi. Myös kuluttajat pohtivat mahdollisuutta arvioida ja vertailla tuotteiden laadun ohella $\mathrm{mm}$. tuotteiden valmistajien vastuullisuutta. Tämä koettiin ongelmaksi arviointikriteerien ja riittävän tiedon puuttuessa.

\section{Vaikutusmahdollisuudet vastuullisuuden edistämiseksi}

Panos-, elintarviketeollisuuden ja kaupan edustajat pitivät vaikutusmahdollisuuksiaan vastuullisuuden edistämisessä hyvinä. Yritysten edustajat ovat tiiviisti mukana alaa koskevan lainsäädännön valmistelussa ennen niiden toimeenpanoa. Sen sijaan monet alkutuottajat pitivät vaikutusmahdollisuuksiaan vastuullisuuden edistämisessä elintarvikeketjussa varsin pieninä. He näkivät vastuullisuuden edistämisen rajoittuvan lähinnä vain omaan toimintaansa. Sen sijaan esimerkiksi vastuullisen kuluttamisen edistämiseksi viljelijät eivät nähneet voivansa vaikuttaa. Todettiin, että ihmiset ostavat kaupasta sitä, mitä on tarjolla ja kauppa myy sitä, mitä ihmiset ostaa - kuka sen sitten päättää?

Kuluttajat kokivat yksittäisen kuluttajan vaikutusmahdollisuudet melko vaatimattomina. Pääasialliset vaikuttamisen keinot olivat asiakkaspalautteen anto joko suoraan elintarviketeollisuuteen tai yleisemmin kaupalle. Toinen tärkeä vaikuttamisen keino ovat kuluttajan omat valinnat. Toisaalta omat valinnat kohdistuvat valikoimaan, jota koskevat päätökset tekevät elintarvikeketjun suuret ja neuvotteluvoimaltaan vahvat toimijat: elintarviketeollisuus ja kauppa.

\section{Johtopäätökset}

Tutkimus on lisännyt ymmärrystä elintarvikeketjun eri toimijoiden laatu- ja vastuukysymyksistä sekä siitä, kuinka laatu- ja vastuuasiat linkittyvät toisiinsa. Tutkimus osoittaa, että elintarvikeketjun eri toimijoiden käsitykset vastuullisuudesta liittyvät keskeisesti tuotelaatuvastuuseen ja vastuuseen tuotteen turvallisuudesta. Alkutuotannon ja teollisuuden rooli on tuotelaadun tuottaminen, ja elintarvikekaupan ja kuluttajien tehtävänä on hyvän tuotelaadun säilyttäminen.

Käsitykset vastuukysymyksistä elintarvikeketjussa olivat osin jaettuja, osin näkemykset vaihtelivat ketjun eri osissa. Yhteiskuntavastuuseen eri toimijat nimesivät suhteellisen kattavasti niitä asioita, joita alan kirjallisuudessakin nostetaan esille. Kuluttajien näkemyksissä yhteiskuntavastuu elintarvike- 
ketjussa on yhtäältä sidoksissa yleisempiin kestävää kehitystä ja eettisiä toimintatapoja koskeviin kysymyksiin ja toisaalta elintarvikeketjua erityisesti koskettaviin kysymyksiin. Edelliset koskevat kaikkea yritystoimintaa toimialasta riippumatta. Jälkimmäisenä mainitut juontavat juurensa elintarvikeketjun toimijoiden päätehtävästä, ruoan tuottamisesta ja jakelusta. Elintarvikkeiden tuotannossa, jakelussa ja kaupassa yhteiskuntavastuu ei voi olla irrallaan laadun eteen tehdystä työstä, vaan laatutyö on osa yhteiskuntavastuuta.

Yritykset joutuvat tasapainoilemaan eri yhteiskuntavastuun osa-alueiden kesken. Taloudellista vastuuta tavoiteltaessa esimerkiksi kustannustehokkuuteen pyrittäessä voidaan vaarantaa yrittäjien ja työntekijöiden hyvinvoinnin ylläpitäminen (sosiaalinen vastuu). Toisaalta juuri taloudellisesti terveellä pohjalla oleva toiminta antaa mahdollisuuksia sosiaalisen ja ympäristövastuun kehittämiseen ja ylläpitämiseen. Kuitenkin elintarvikeketjun yrityksillä on hyvin vähän tietoa siitä, mitä kuluttajakansalaiset vastuulliselta toimijalta elintarvikeketjussa odottavat. Tällöin yrityksen on vaikea kilpailustrategisesti edistää vastuullista toimintaansa.

Tulosten perusteella kuluttajat arvostavat tiedon saannin helppoutta ja yrityksen rehellistä toimintatapaa. Läpinäkyvyys on osa vastuullisuutta ja luottamuksen rakentamista elintarvikeketjun ja kuluttajan välillä. Läpinäkyvyys koettiin eri toimijoiden keskuudessa sisällöltään määrittelemättömänä käsitteenä, mikä nostaa esille useita kysymyksiä. Missä määrin läpinäkyvyys ja liikesalaisuus ovat ristiriidassa keskenään? Minkälaisilla mittareilla eri yritysten tai elintarvikeketjujen läpinäkyvyyttä olisi mahdollista vertailla? Onko yrityksen mahdollista saavuttaa läpinäkyvyydellä kilpailuetua verrattuna muihin yrityksiin?

\section{Kirjallisuus}

Elintarviketeollisuusliitto 2004. Vastuullisesti tuotettua ruokaa pellolta pöytään. Elintarviketalouden ympäristövastuun raportoinnin käsikirja. Helsinki: Elintarviketeollisuusliitto ry. 26. s.

Elintarviketeollisuusliitto 2005. Yhteiskuntavastuu elintarvikeketjussa. Selvitys vastuullisista toimintatavoista ja käytännöistä kotimaisessa elintarvikeketjussa. Helsinki: Elintarviketeollisuusliitto ry. 42.s.

Kalpala, A. 2004. Johdantopuheenvuoro. Julkaisussa: Järvinen, R. (toim.). Yhteiskuntavastuu. Näkökulmia yritysten ja julkisyhteisöjen yhteiskunnalliseen vastuuseen. Tampere: Tampere University Press. s. 13-16.

Kujala, J. 2001. Liiketoiminnan moraalia etsimässä - Suomalaisten teollisuusjohtajien sidosryhmänäkemykset ja moraalinen päätöksenteko. Väitöskirja. Jyväskylä Studies in Business and Economics numero 11, 217 s., Jyväskylä 2001 .

Lämsä, A-M. 2001. Organizational downsizing and the Finnish manager from an ethical perspective. Jyväskylä Studies in Business and Economics 12. Jyväskylä: Jyväskylän yliopisto. 61 p.

Niskala, M. \& Tarna, K. 2003. Yhteiskuntavastuun raportointi. Jyväskylä: KHT-Media.

Rytteri, T. 2002. Metsäteollisuusyrityksen luonto: tutkimus Enso-Gutzeitin ympäristö- ja yhteiskuntavastuun muotoutumisesta. Maantieteen laitos, Publications, No: 10. Oulu: Oulun yliopisto.

Takala, T. 1986. Yrityksen yhteiskunnallisen vastuun käsite sekä yrityksen yhteiskunnallisen vastuun ja yritystoiminnan ideologiat vuosina 1930-1940 sekä 1972-1982. Jyväskylä: taloustieteen laitos.

Takala, T. 1991. Managerial Beliefs Concerning Social Responsibility of the Firm. A Trail to Identify and Understand Entrepeneurs' and Managers' Social Responsibility Beliefs as Discoursive Phenomenon. Doctoral Dissertation. Jyväskylä Studies in Computer Science, Economics and Statistics, 16. Jyväskylä: Jyväskylän yliopisto.

Teollisuus ja Työnantajat 2004. Kestävä kehitys ja kilpailukyky - TT:n näkemyksiä kestävän kehityksen edellytyksistä. Viitattu 24.11.2005. Saatavilla internetissä: http://www.ek.fi/arkisto/ekarchive/20040428-111354-2828.pdf

Virtanen, A. 2002. Laskentatoimen ammattilaisen hyvästä moraalista hyötyvät omistajat, sidosryhmät ja yhteiskunta. Väitöskirja. Jyväskylä studies in business and economics, numero 19, 184 s., Jyväskylä 2002.

Wilenius, M. 2005. Towards the age of corporate responsibility? Emerging challenges for the business world. Futures 37, 133-150. 